\title{
Indian Commodity Derivatives Market and Price Inflation
}

\author{
${ }^{1}$ Nissar A. Barua, ${ }^{2}$ Devajit Mahanta \\ ${ }^{I}$ Associate Professor, Department of Economics, Gauhati University, Assam, India, \\ ${ }^{2}$ Director, SDM Advisory Services Pvt. Ltd., Assam, India,
}

\begin{abstract}
Since its revival post-1991, commodity derivatives trade in India had experienced explosive growth, both in volumes and value over the years across all contracts that were in operation for major agricultural commodities, metal and energy. However derivatives trade in agricultural commodities was confronted by a major crisis when the Government of India imposed a temporary ban on futures trading of selected items in 2007-08 as part of its anti-inflationary measures.

But given the insignificant volumes of trading in commodity futures of all the recently banned commodities it is often argued that futures trading cannot and do not have any direct impact on price rise of these commodities. However test on existing data reveals that the effect of futures prices on spot prices for different commodities differs which implies that there is no uniform impact of commodity derivatives trading on the spot prices of the wide assortment of commodities that are traded. This actual unfolding of events vindicate the position that inflationary pressures stems from a number of factors, including supply side constraint, the global rise in prices of food and oil, the diversion of land for bio-fuel production, loose monetary policy in emerging economies, and the adoption of an expansionary fiscal policy. Hence the policy of across-the-board restriction of derivatives trading in agricultural commodities appears to be unjustifiable, inequitable, and counter-productive.
\end{abstract}

\section{Introduction}

Derivatives were developed centuries ago as financial instruments to hedge risk associated with price fluctuations. Although derivatives was initially conceived for the commodity market, in recent years there had been a tremendous development in financial derivatives market both in terms of trade volume and in the variety of instruments used. The expanding domain of the derivatives market is primarily induced by the huge volatility in the global financial and commodity market and facilitated by the revolution in information technology.

Commodity derivatives markets trades in basic and raw products under standardized contracts in regulated commodity exchanges. Although commodity derivatives were traditionally developed for risk management however in recent years they are growing in popularity as investment tools. Thus a contemporary commodity derivatives market provides a risk averse participant to secure his position as an hedger while at the same time allow speculators and arbitrageurs to operate to profit from the uncertainty that prevails in the market.

\section{Derivatives Market in India:}

Although commodity futures has a long history in India, its growth had been at best sketchy, especially in the period 1950 to1990 where it was in a state of hibernation. It was only after the post 1990 reforms and some goading by the Kabra committee (Ministry of Civil Supplies, Consumer Affairs, Food \& Public Distribution, 1993), that commodity derivatives market saw the new light of day. Accepting the recommendations of the committee on the reintroduction of futures trading and strengthening of Forward Market Commission (FMC), the Government sanctioned futures trading in seventeen commodities. The liberalisation process initiated was further carried forward in 2002-2003 when the government notified the withdrawal of all prohibitions on commodity derivatives trading providing a big boost to the Indian commodity derivatives market.

To facilitate commodity derivatives trade, four national level commodity exchanges namely, National Multi Commodity Exchange of India (NMCE), the Multi Commodity Exchange (MCX), the National Commodity Derivatives Exchange of India (NCDEX) and the National Board of Trade (NBOT) were registered with the FMC in 2003. Apart from them there are 25 regional commodity derivatives exchanges in India where derivatives contracts on nearly 86 commodities are traded.

Since its revival commodity derivatives trade had experienced explosive growth, both in volumes and value over the years across all contracts that were in operation for major agricultural commodities, metal and energy. 
Indian Commodity Derivative Market And Price Inflation

Table: 1 Value and Volume of Trade in Commodity Derivatives Exchanges in India

\begin{tabular}{|l|l|l|l|l|}
\hline Year & $\mathbf{2 0 0 2 - 0 3}$ & $\mathbf{2 0 0 3 - 0 4}$ & $\mathbf{2 0 0 4 - 0 5}$ & $\mathbf{2 0 0 5 - 0 6}$ \\
\hline $\begin{array}{l}\text { Volume of Trading } \\
\text { (in trillion KG) }\end{array}$ & $\begin{array}{l}314.4 \\
(44.4)\end{array}$ & $\begin{array}{l}492.9 \\
(56.7)\end{array}$ & $\begin{array}{l}1942.1 \\
(294)\end{array}$ & $\begin{array}{l}6685.09 \\
(244)\end{array}$ \\
\hline $\begin{array}{l}\text { Value of Trading } \\
\text { (Rs. In trillion) }\end{array}$ & $\begin{array}{l}0.66 \\
(92.8)\end{array}$ & $\begin{array}{l}1.29 \\
(95.4)\end{array}$ & $\begin{array}{l}5.71 \\
(342.6)\end{array}$ & $\begin{array}{l}21.34 \\
(274)\end{array}$ \\
\hline
\end{tabular}

Note: Figure in bracket indicates percentage change over previous year.

Source: Ministry of Consumer Affairs, Food and Public Distribution, 2006

Although agricultural commodities dominated trade and led the initial growth spurt, it had to concede the lead to bullion and metals in 2006-07. The growth in derivatives trade in 2006-07 was almost wholly (88.7\%) accounted for by bullion and metals, with agricultural commodities contributing a small fraction $(10.7 \%)$. Futures market growth in 2006-07 appeared to have bypassed agricultural commodities which were partly due to the stringent regulations, like margins limits, imposed on agriculture commodities and the dampening of sentiments due to suspension of trade in few commodities. The downtrend for agricultural futures continued in 2007-08 where volumes in trade fell by a huge 28.5 percent. The overwhelming bulk of this decline is accounted for by chickpeas, Maize, Mentha Oil, Guar seed, Potato, Guar Gum, Chillies and Cardamom which constituted 57.9 percent of total futures trade in agricultural commodities in 2006-07, and which declined by over 66.4 percent in 2007-08.

Commodity derivatives trade in agricultural commodities was confronted by a major crisis when the Government of India imposed a temporary ban on futures trading of red gram (tur), black gram (urad), chickpeas (channa), soybean oil, potato, rubber, wheat and rice in three phases in 2007-08 as measures to curb inflation. Even though wheat, rice, red gram and black gram together accounted for only 6.65 percent of the total value of futures trading in all agricultural commodities in 2006-07, their delisting in the commodity derivatives trade is perceived to be responsible for adversely affecting market sentiments leading to a subsequent general downturn in futures trading in agricultural commodities.

Table-2: Commodity Group-wise Value of Trade (Rupees Lakh Crs)

\begin{tabular}{|l|l|l|l|l|}
\hline $\begin{array}{l}\text { Commodity } \\
\text { Groups }\end{array}$ & $\mathbf{2 0 0 4 - 0 5}$ & $\mathbf{2 0 0 5 - 0 6}$ & $\mathbf{2 0 0 6 - 0 7}$ & $\mathbf{2 0 0 7 - 0 8}$ \\
\hline $\begin{array}{l}\text { Bullion \& \& } \\
\text { other metals }\end{array}$ & $\begin{array}{l}1.80 \\
(31.47)\end{array}$ & $\begin{array}{l}7.79 \\
(36.15)\end{array}$ & $\begin{array}{l}21.29 \\
(57.90)\end{array}$ & $\begin{array}{l}26.24 \\
(64.55)\end{array}$ \\
\hline Agriculture & $\begin{array}{l}3.90 \\
(68.18)\end{array}$ & $\begin{array}{l}11.92 \\
(55.31)\end{array}$ & $\begin{array}{l}13.17 \\
(35.82)\end{array}$ & $\begin{array}{l}9.41 \\
(23.15)\end{array}$ \\
\hline Energy & $\begin{array}{l}0.02 \\
(0.35)\end{array}$ & $\begin{array}{l}1.82 \\
(8.45)\end{array}$ & $\begin{array}{l}2.31 \\
(6.28)\end{array}$ & $\begin{array}{l}5.00 \\
(12.30)\end{array}$ \\
\hline Others & $\begin{array}{l}0.00 \\
(0.00)\end{array}$ & $\begin{array}{l}0.02 \\
(0.09)\end{array}$ & $\begin{array}{l}0.001 \\
(0.00)\end{array}$ & $\begin{array}{l}0.00 \\
(0.00)\end{array}$ \\
\hline Total & $\begin{array}{l}\mathbf{5 . 7 2} \\
(\mathbf{1 0 0 . 0 0 )}\end{array}$ & $\begin{array}{l}\mathbf{2 1 . 5 5} \\
(\mathbf{1 0 0 . 0 0 )}\end{array}$ & $\begin{array}{l}\mathbf{3 6 . 7 7} \\
(\mathbf{1 0 0 . 0 0 )}\end{array}$ & $\begin{array}{l}\mathbf{4 0 . 6 5} \\
(\mathbf{1 0 0 . 0 0})\end{array}$ \\
\hline
\end{tabular}

Note: Figures in parenthesis indicate percentage to total value

Source: Ministry of Consumer Affairs, Food \& Public Distribution , 2008

\section{Commodity Derivatives and Inflation:}

Theoretically the future price of derivatives tends towards the spot price of the underlying as the point of delivery approaches. This happens under two situations.

\section{Case-1: If the future price is greater than the spot price}

Here the market presents a clear arbitrage opportunity where traders short futures contract, buy the asset, and then make the delivery at maturity. The difference between the future price and the spot price will constitute the profit of the trader. As the arbitrage opportunity is exploited by traders, future price tends to fall and spot price rise resulting in the correction of the initial disparity. 


\section{Case-2: If the future price is less than the spot price}

The alternate arbitrage strategy is executed where the trader sells the commodity, invests the proceeds at the ruling interest, and takes a long position in the futures contract. Thus the arbitrage intervention induces the spot price to fall and future price to rise, so that the parity between them is restored.

Hence commodity derivatives trading is credited with promoting price discovery where arbitrage intervention generates forces which corrects disparity between future and spot prices.

However in the context of India, there is no unanimity of opinions on the relationship between commodity derivatives trade and price level. The lack of convergence in this regard has recently come more into focus with the state ban of various commodities in commodity derivatives market on the ground that speculations arising from futures trade induces inflation.

Existing literature reveals diametrically opposite and extreme positions on this controversial ban. Those opposing the ban contend that the futures market provides farmers an opportunity to hedge risks on the basis of signals about the future movements of prices and in the process assist in price discovery. That also highlights the fact that those futures contracts enable farmers to avoid the cost of storing the product till the sale is made. In that sense imposition of a ban in futures trade of agricultural commodities goes against the interest of the farmers. On the other hand, proponents of the selective ban on futures trading argue that futures trading encourage unnecessary speculation leading to price-rise. In this context, Chopra (2008) contends that traders buy out the products cheaply through future contracts and raise the prices artificially by creating false scarcity.

At the operational level, the average daily turnover of 25 commodity exchanges put together barely crosses Rs.8000-9000 crore, out of which the share of fine cereal grains (wheat and rice) is insignificant, ranging below Rs.30 crore per day. Again red gram, black gram, chickpeas brown, soya oil and potato accounted for less than 15 percent of the turnover (Ministry of Finance, 2007-08). Given the insignificant volumes of trading in commodity futures of all the recently banned commodities it is often argued that futures trading cannot and do not have any direct impact on price rise of these commodities. The line of argument can be perceived by the disparity between the 70 million tonnes of wheat produced in India per annum and the only 20000 tonnes that are traded in the commodity derivatives market.

On the other hand, several studies have revealed the efficacy of commodity derivatives market as an instrument for maintaining price stability. Newbery (1990) observed that since commodity derivatives markets reduce risk, they encourage firms to supply more output and thus reduce the spot price in times of inflation. Whereas Turnovsky \& Campbell (1985) arrived at the same conclusion by arguing that as derivatives market reduce the price risk of holding inventories subsequently larger inventories are held and prices tend to stabilize as a consequence.

The paper seeks

- To analyse the interaction between the spot market and the commodity derivative market in the context of price movements in the respective markets.

- To estimate the effect of movement of futures prices on spot prices.

\section{Trends in Future and Spot prices in the Indian Commodity Market:} An Empirical Analysis

In this section the effect of the derivatives market on spot market is analysed in terms of future and spot price trends for important commodities, such as gold, refined soybean oil, wheat and rubber.

In table-3, gold prices for 42 months are indicated both for the future market (MCX) and spot market (monthly average price of Mumbai, Ahmadabad, Delhi and Kolkata). In that period future price of gold has exhibited a 124.03 percent increase whereas the increased in the spot price was 112.82 percent.

Similarly in table-4, trends of both future and spot price of refined soybean oil is indicated for period April 2004 to April 2008. In a period of 48 months future price has exhibited an increased in 21 percent whereas spot price has gone up by, 24.35 percent.

Table-5 reveals the price trend of wheat, which is one of the two most important staple crops in India. Time series data for a period of 26 months indicate future price over that period had gone up by 39.61 percent whereas the increase in spot price had been marginally higher at 39.97 percent.

Finally trend in both future and spot price of rubber are presented in table- 6 for 29 months covering the period from January 2005 to May 2008. In this period future price of rubber had increased by 115.22 percent whereas the increase in spot price higher at 130.83 percent.

Table-3: Gold Prices

Price: Rs/10gm 
Indian Commodity Derivative Market And Price Inflation

\begin{tabular}{|l|l|l|l|l|l|}
\hline Month/Year & $\begin{array}{l}\text { MCX } \\
\text { futures } \\
\text { prices }\end{array}$ & $\begin{array}{l}\text { Average Spot } \\
\text { Prices } \\
\text { (Mumbai, } \\
\text { Ahmadabad, } \\
\text { Delhi \& Kolkata) }\end{array}$ & Month/Year & $\begin{array}{l}\text { MCX } \\
\text { futures } \\
\text { prices }\end{array}$ & $\begin{array}{l}\text { Average } \\
\text { Prices } \\
\text { (Mumbai, } \\
\text { Ahmadabad, } \\
\text { Delhi \& Kolkata) }\end{array}$ \\
\hline Jul-05 & 6084 & 6047 & Apr-07 & 9203 & 9313 \\
\hline Aug-05 & 6263 & 6255 & May-07 & 8694 & 8874 \\
\hline Sep-05 & 6731 & 6537 & June-07 & 8710 & 8863 \\
\hline Oct-05 & 6822 & 6871 & Jul-07 & 8708 & 8736 \\
\hline Nov-05 & 7416 & 7129 & Aug-07 & 8935 & 8814 \\
\hline Dec-05 & 7638 & 7587 & Sep-07 & 9530 & 9295 \\
\hline Jan-06 & 8166 & 7924 & Oct-07 & 10083 & 9669 \\
\hline Feb-06 & 8111 & 8030 & Nov-07 & 10033 & 10306 \\
\hline Mar-06 & 8382 & 8065 & Dec-07 & 10083 & 10280 \\
\hline Apr-06 & 9609 & 8861 & Jan-08 & 11707 & 11264 \\
\hline May-06 & 9526 & 9907 & Feb-08 & 12396 & 11870 \\
\hline Jun-10 & 9220 & 8956 & Mar-08 & 11920 & 12634 \\
\hline Jul-06 & 9560 & 9560 & Apr-08 & 11370 & 11834 \\
\hline Aug-06 & 9554 & 9550 & May-08 & 12199 & 12116 \\
\hline Sep-06 & 8859 & 9037 & Jun-08 & 12879 & 12333 \\
\hline Oct-06 & 8894 & 8720 & Jul-08 & 12618 & 13013 \\
\hline Nov-06 & 9269 & 9156 & Aug-08 & 11895 & 11826 \\
\hline Dec-06 & 9265 & 9143 & Sep-08 & 13192 & 12215 \\
\hline Jan-07 & 9242 & 9075 & Oct-08 & 11630 & 12682 \\
\hline Feb-07 & 9628 & 9511 & Nov-08 & 13125 & 12175 \\
\hline Mar-07 & 9339 & 9361 & Dec-08 & 13630 & 12869 \\
\hline
\end{tabular}

Source: Commodity Insights Year Book-2008-09, MCX 
Indian Commodity Derivative Market And Price Inflation

\section{Table-4: Refined Soybean Oil Prices}

Price: Rs/10kg

\begin{tabular}{|l|l|l|l|l|l|}
\hline Month/Year & $\begin{array}{l}\text { MCX } \\
\text { Futures } \\
\text { Prices }\end{array}$ & $\begin{array}{l}\text { Spot } \\
\text { Prices } \\
\text { Mumbai }\end{array}$ & Month/Year & $\begin{array}{l}\text { MCX } \\
\text { Prices }\end{array}$ & $\begin{array}{l}\text { Spot } \\
\text { Prices } \\
\text { Mumbai }\end{array}$ \\
\hline Apr-2004 & 460 & 463.59 & Apr-2006 & 413.9 & 395.44 \\
\hline May-2004 & 436.9 & 466.13 & May-2006 & 406.9 & 412.71 \\
\hline Jun-2004 & 431.7 & 445.24 & Jun-2006 & 429.55 & 412.81 \\
\hline Jul-2004 & 454.3 & 462.37 & Jul-2006 & 436.2 & 424.47 \\
\hline Jul-2004 & 454.3 & 462.37 & Aug-2006 & 423 & 446.6 \\
\hline Aug-2004 & 462 & 477.74 & Sep-2006 & 428.95 & 439.94 \\
\hline Sep-2004 & 409.7 & 452.96 & Oct-2006 & 465.6 & 430.82 \\
\hline Oct-2004 & 414.3 & 422.94 & Nov-2006 & 468.65 & 462.31 \\
\hline Nov-2004 & 411.4 & 416.93 & Dec-2006 & 452.15 & 471.33 \\
\hline Dec-2004 & 397.6 & 408.05 & Jan-2007 & 443.15 & 474.49 \\
\hline Jan-2005 & 357.7 & 391.83 & Feb-2007 & 468.35 & 455.75 \\
\hline Feb-2005 & 382 & 375.59 & Mar-2007 & 488.25 & 462.39 \\
\hline Mar-2005 & 397.5 & 387.12 & Apr-2007 & 486.7 & 483.07 \\
\hline Apr-2005 & 381.4 & 387.44 & May-2007 & 496.55 & 484.98 \\
\hline May-2005 & 377 & 376.9 & Jun-2007 & 505.6 & 485.32 \\
\hline Jun-2005 & 371.5 & 374.55 & Jul-2007 & 479.15 & 503.45 \\
\hline Jul-2005 & 373 & 376.52 & Aug-2007 & 487.05 & 492.25 \\
\hline Aug-2005 & 373.5 & 366.79 & Sep-2007 & 505.15 & 489.75 \\
\hline Sep-2005 & 363.4 & 360.71 & Oct-2007 & 532.15 & 496.25 \\
\hline Oct-2005 & 357.95 & 363.62 & Nov-2007 & 550.8 & 530.22 \\
\hline Nov-2005 & 339.55 & 363.86 & Dec-2007 & 586.95 & 550.02 \\
\hline Dec-2005 & 343.2 & 359.38 & Jan-2008 & 671.2 & 593.13 \\
\hline Jan-2006 & 373.9 & 351.3 & Feb-2008 & 589 & 616.21 \\
\hline Feb-2006 & 375.1 & 366.43 & Mar-2008 & 570.2 & 676.67 \\
\hline Mar-2006 & 422.45 & 384.51 & Apr-2008 & 583.3 & 576.91 \\
\hline
\end{tabular}

Source: Commodity Insights Year Book-2008-09, MCX 
Indian Commodity Derivative Market And Price Inflation

Table-5: Monthly Average Future \& Spot Price of Wheat in India

Price Rs./qtl

\begin{tabular}{|l|l|l|}
\hline Period & Monthly Average & $\begin{array}{l}\text { Monthly Average } \\
\text { Spot Price } \\
\text { (Delhi) }\end{array}$ \\
\hline Jan-05 & 764.56 & 762.50 \\
\hline Feb-05 & 775.75 & 768.00 \\
\hline Mar-05 & 750.29 & 733.50 \\
\hline Apr-05 & 687.07 & 687.50 \\
\hline May-05 & 723.57 & 726.00 \\
\hline Jun-05 & 757.07 & 755.00 \\
\hline Jul-05 & 759.88 & 761.50 \\
\hline Aug-05 & 800.87 & 756.00 \\
\hline Sep-05 & 855.08 & 760.50 \\
\hline Oct-05 & 892.38 & 794.00 \\
\hline Nov-05 & 977.34 & 853.50 \\
\hline Dec-05 & 959.15 & 895.25 \\
\hline Jan-06 & 928.37 & 971.50 \\
\hline Feb-06 & 796.47 & 972.00 \\
\hline Mar-06 & 928.37 & 903.95 \\
\hline Apr-06 & 796.47 & 801.25 \\
\hline May-06 & 852.55 & 848.00 \\
\hline Jun-06 & 860.49 & 854.35 \\
\hline Jul-06 & 872.50 & 877.00 \\
\hline Aug-06 & 949.06 & 946.45 \\
\hline Sep-06 & 998.45 & 994.80 \\
\hline Oct-06 & 1039.66 & 1055.25 \\
\hline Nov-06 & 1133.33 & 1135.50 \\
\hline Dec-06 & 1107.09 & 1105.00 \\
\hline Jan-07 & 1079.86 & 1057.56 \\
\hline Feb-07 & 1067.58 & 1068.35 \\
\hline Soure & Pon & \\
\hline
\end{tabular}

Source: Commodity Insights Year Book-2008-09, MCX

Table-6: Rubber Future \& Spot Price Comparative Analysis Prices Rs./qtl

\begin{tabular}{|l|l|l|l|l|l|}
\hline $\begin{array}{l}\text { Month/ } \\
\text { Year }\end{array}$ & $\begin{array}{l}\text { Monthly } \\
\text { Average } \\
\text { MCX } \\
\text { futures } \\
\text { prices }\end{array}$ & $\begin{array}{l}\text { Monthly } \\
\text { Average } \\
\text { MCX Spot } \\
\text { prices } \\
\text { (Kottayam) }\end{array}$ & $\begin{array}{l}\text { Month/ } \\
\text { Year }\end{array}$ & $\begin{array}{l}\text { Monthly } \\
\text { Average } \\
\text { MCX } \\
\text { futures } \\
\text { prices }\end{array}$ & $\begin{array}{l}\text { Monthly } \\
\text { Average } \\
\text { Rubber } \\
\text { MCX spot } \\
\text { prices } \\
\text { (Kottayam) }\end{array}$ \\
\hline Jan-05 & 5322.50 & 5323.00 & Oct-06 & 8498.00 & 8753.80 \\
\hline Feb-05 & 5200.00 & 5149.50 & Nov-06 & 8115.00 & 8277.50 \\
\hline Mar-05 & 5595.00 & 5468.75 & Dec-06 & 8470.00 & 8673.80 \\
\hline
\end{tabular}


Indian Commodity Derivative Market And Price Inflation

\begin{tabular}{|c|c|c|c|c|c|}
\hline Apr-05 & 5875.00 & 5845.84 & Jan-07 & 10229.00 & 9785.00 \\
\hline May-05 & 6150.00 & 6236.07 & Feb-07 & 9775.00 & 9786.83 \\
\hline Jun-05 & 6195.00 & 6185.53 & Mar-07 & 8883.00 & 9037.23 \\
\hline Jul-05 & 6650.00 & 6579.76 & Apr-07 & 8890.00 & 8994.08 \\
\hline Aug-05 & 6285.00 & 6071.57 & May-07 & 8739.50 & 8713.81 \\
\hline Sep-05 & 6143.50 & 6078.36 & June-07 & 8123.00 & 8099.07 \\
\hline Oct-05 & 6587.50 & 6594.69 & Jul-07 & 8025.50 & 7966.00 \\
\hline Nov-05 & 6562.50 & 6599.96 & Aug-07 & 8712.00 & 8779.51 \\
\hline Dec-05 & 7062.50 & 6960.70 & Sep-07 & 8750.00 & 8882.00 \\
\hline Jan-06 & 7583.50 & 7400.44 & Oct-07 & 9480.00 & 9510.15 \\
\hline Feb-06 & 7989.00 & 8069.58 & Nov-07 & 9800.00 & 9681.28 \\
\hline Mar-06 & 8137.50 & 8088.07 & Dec-07 & 9460.00 & 9255.88 \\
\hline Apr-06 & 8852.50 & 8671.54 & Jan-08 & 9503.50 & 9465.65 \\
\hline Мay-06 & 10351.50 & 9910.77 & Feb-08 & 9790.00 & 9714.84 \\
\hline Jun-10 & 10752.00 & 10711.15 & Mar-08 & 10224.50 & 10114.25 \\
\hline Jul-06 & 9895.00 & 9806.68 & Apr-08 & 10701.00 & 10984.92 \\
\hline Aug-06 & 9136.50 & 9199.38 & May-08 & 11454.00 & 12287.31 \\
\hline Sep-06 & 8280.00 & 8221.57 & & & \\
\hline
\end{tabular}

Source: Commodity Insights Year Book-2008-09, MCX

On the basis of the data presented in the above mentioned tables four null hypothesis are formulated respectively for four commodities that hypotheses that-

Future prices in commodity derivative market do not affect price in the spot market.

The hypotheses are tested on the basis of four regression models constructed respectively for the four commodities.

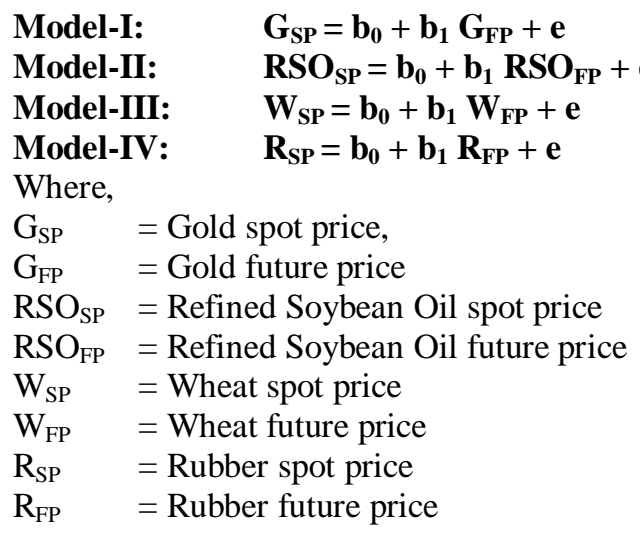


Initially the Augmented Dickey-Fuller test is undertaken on the four sets of time series data to examine whether they are stationary (Annexure-I, Annexure-II, Annexure-III \& Annexure-IV). All the four sets of data are found to be non-stationary as a result of which the first difference of the four data series is adopted to test the respective models.

The results of the linear regression which is run to determine the relationship between spot price and future price of the four commodities is presented in Box-1.

\begin{tabular}{|l|l|l|l|l|l|l|l|}
\hline MODEL & $\mathrm{R}^{2}$ & $\begin{array}{l}\text { Durbin } \\
\text { Watson }\end{array}$ & $\mathrm{F}$ & Sig. & $\mathrm{B}$ & $\mathrm{t}$ & $\mathrm{sig}$. \\
\hline $\mathrm{I}$ & .148 & 2.749 & 6.750 & .013 & .311 & 2.598 & .013 \\
\hline $\mathrm{II}$ & .004 & 1.710 & .166 & .686 & .053 & .407 & .686 \\
\hline III & .218 & 1.325 & 6.421 & .019 & .35 & 2.534 & .019 \\
\hline IV & .862 & 2.078 & 236.75 & .000 & .911 & 15.387 & .000 \\
\hline
\end{tabular}

Note: Model-I:

Predictors: (Constant), Gold Future Price

Dependent: Gold Spot Price

Model-II:

Predictors: (Constant), Refined Soyabean Oil Future Price

Dependent: Refined Soyabean Oil Spot Price

Model-III:

Predictors: (Constant), Wheat Future Price

Dependent: Wheat Spot Price

Model-IV:

Predictors: (Constant), Rubber Future Price

Dependent: Rubber Spot Price

For Model-I, the coefficient of determination is estimated at 0.148 , which implies that 14.8 percent of the variation in spot price of gold can be accounted for by a change in its future price. Again the $\mathrm{F}$ value is estimated at 6.750 , which is significant at $p<.05$. This implies that there is less than 5 percent probability that a positive $\mathrm{F}$ ratio will emerge by chance alone, thus indicating that this regression model overall predicts variation in gold spot price efficiently.

The $b_{1}$ representing the gradient of the regression line is estimated at 0.311 , implying that a 100 unit rise in the future price will cause the spot price to increase by 31.1 units. The $t$ value for $b_{1}$ is estimated at 1.437 with the corresponding $p<0.05$. This implies that the probability of $b_{1}$ being equal to zero is less than 5 percent, on the basis of which that null hypothesis asserting future price of gold has no effect on the spot price, is rejected.

In Model-II, the coefficient of determination is estimated at 0.004, which implies that only 4 percent of the variation in spot price of refined soybean oil can be accounted by a change in its future price. The $\mathrm{F}$ value is observed to be insignificant indicating that the regression model is inefficient in predicting spot price of refined soybean oil on the basis of its future price.

The $b_{l}$ is also found to be insignificant implying that future price of refined soybean oil has no significant impact on its spot price.

In Model-III, the value of $\mathrm{R}^{2}$ reveals that 21.8 percent of the variation in spot price of wheat can be accounted by changes in the future price. Besides the $\mathrm{F}$ value is significant at 5 percent implying that the model efficiently explains variation in the spot price of wheat by variation in its future price.

The $b_{1}$ value is found to be significant at 0.35 implying that a hundred rupees increase in future price of wheat cause to spot price to go up by rupees thirty five.

In Model-IV, the coefficient of determination is estimated at .862 indicating that 86.2 percent variation in spot price of rubber can be accounted for by changes in the future price. Very high $\mathrm{F}$ value of 236.75 which is significant at 1 percent, reveal that this model is highly efficient in predicting variation in spot price of rubber. The $b_{1}$ is estimated at 0.911 implying that hundred rupees increase in future price of rubber will induce the spot price to go up by 91.1 rupees. Besides t value of 15.387 is found to be significant at 1 percent implying that future price affects spot price. Hence we reject the fourth null hypothesis which states that future price in rubber do not affect spot price.

Thus tests were carried out to determine the impact of future prices on spot prices for four selected commodities i.e. gold, refined soybean oil, wheat and rubber. The first test which was undertaken in the most 
commonly traded metal item in India (i.e. gold) reveals that variation in future prices do have a significant impact on the spot price. On the other hand, when the test was repeated on refined soybean oil, the results were a contradiction to the earlier outcome as fluctuations of future prices of refined soyabean oil were found to have no significant effect on their spot prices.

However tests conducted on wheat and rubber endorsed the first result which was found for gold, where future prices were found to have a significant impact on spot prices. Hence from the outcomes of the tests we can conclude that increase in futures prices in general (except for some commodities like refined soybean oil) do induce a rise in spot prices. However the effect of futures prices on spot prices for different commodities differs which implies that there is no uniform impact of commodity derivatives trading on the spot prices of the wide assortment of commodities that are traded.

\section{Conclusion:}

In India, high inflationary pressures in 2007-08 lead to a close scrutiny into the functioning of commodity derivatives market. Acting on the premise that speculation in commodity derivatives market was inducing steep price rise in agriculture commodities, the government ordered delisting of futures contracts in red gram, black gram, chickpeas, wheat, rice, potato, refined soybean oil, and rubber. The ban resulted in a huge loss of trading volumes for the commodity derivatives exchanges, but did not have any significant impact on food prices despite claims by the government that the adoption of such a strategy would help to curb inflation as speculators in derivatives markets drive up prices beyond their true value.

This actual unfolding of events vindicate the position that inflationary pressures stems from a number of factors, including supply side constraint, the global rise in prices of food and oil, the diversion of land for biofuel production, loose monetary policy in emerging economies, and the adoption of an expansionary fiscal policy. Hence the policy of across-the-board restriction of derivatives trading in agricultural commodities appears to be unjustifiable, inequitable, and counter-productive. If any anti-inflationary strategy pertaining to the commodity derivatives market is to be relevant and efficient then it must be executed on a commodity-tocommodity basis and only after substantive evidence of its inflationary character is gathered and tested for authentication.

\section{References}

[1.] Chopra S. (2008) 'Did agri futures have a premature start'? [online]

Available:http://economictimes.indiatimes.com/Opinion/Debate/Did_agri_futures_have_a_premature_start/articleshow/3037768.cm s Accessed on 05.06.2011

[2.] Ministry of Consumer Affairs, Food and Public Distribution (2006) 'Report of the Standing Committee on Food, Consumer Affairs and Public Distribution', Government of India.

[3.] Ministry of Consumer Affairs, Food and Public Distribution (2008) Report of the Expert Committee to study the impact of future trading on agricultural commodity price', Government of India.

[4.] Ministry of Finance (2007-08) 'Prices and Monetary Management',[online]

Available:http://indiabudget.nic.in/es2007-08/chapt2008/chap42.pdf Accessed on 10.07.2011

[5.] Newbery D.M. (1990) 'Cartels, Storage, and the Suppression of Future Markets', European Economic Review, 34 (7), pp 10411060 .

[6.] Turnovsky S.J. and Campbell R.B. (1985) 'The Stabilizing and Welfare Properties of Futures Markets: A Simulation Approach', International Economic Review, 26: pp 277-303.

\section{Annexure}

\section{Annexure-I}

Null Hypothesis: MCX Gold Future Price has a unit root

Exogenous: Constant

Lag Length: 0 (Automatic based on SIC, MAXLAG=9)

\begin{tabular}{lccc}
\hline \hline & t-Statistic & Prob.* \\
\hline \hline Augmented Dickey-Fuller test statistic & -0.939228 & 0.7654 \\
\hline Test critical values: & 1\% level & -3.600987 & \\
& 5\% level & -2.935001 & \\
& 10\% level & -2.605836 & \\
\hline
\end{tabular}

*MacKinnon (1996) one-sided p-values.

Augmented Dickey-Fuller Test Equation

Dependent Variable: D(MCX GOLD FUTURE

PRICE)

Method: Least Squares

Date: 06/25/11 Time: 10:49 
Sample (adjusted): 242

Included observations: 41 after adjustments

Null Hypothesis: D(MCX Gold Future Price) has a unit root

Exogenous: Constant

Lag Length: 0 (Automatic based on SIC, MAXLAG=9)

\begin{tabular}{lrcc}
\hline \hline & t-Statistic & Prob.* \\
\hline \hline Augmented Dickey-Fuller test statistic & -7.859046 & 0.0000 \\
\hline Test critical values: & 1\% level & -3.605593 & \\
& 10\% level & -2.936942 & \\
& & -2.606857 & \\
\hline \hline
\end{tabular}

*MacKinnon (1996) one-sided p-values.

Augmented Dickey-Fuller Test Equation

Dependent Variable: D(MCXFP,2)

Method: Least Squares

Date: 06/25/11 Time: 10:51

Sample (adjusted): 342

Included observations: 40 after adjustments

Null Hypothesis: Gold Spot Price has a unit root

Exogenous: Constant

Lag Length: 0 (Automatic based on SIC, MAXLAG=9)

\begin{tabular}{lccc}
\hline \hline & t-Statistic & Prob.* \\
\hline \hline Augmented Dickey-Fuller test statistic & -1.098265 & 0.7075 \\
\hline Test critical values: & 1\% level & -3.600987 & \\
& 5\% level & -2.935001 & \\
& $10 \%$ level & -2.605836 & \\
\hline \hline
\end{tabular}

*MacKinnon (1996) one-sided p-values.

Augmented Dickey-Fuller Test Equation

Dependent Variable: D(Gold Spot Price)

Method: Least Squares

Date: 06/25/11 Time: 10:57

Sample (adjusted): 242

Included observations: 41 after adjustments

Null Hypothesis: D(Gold Spot Price) has a unit root

Exogenous: Constant

Lag Length: 0 (Automatic based on SIC, MAXLAG=9)

\begin{tabular}{lccc}
\hline \hline & t-Statistic & Prob.* \\
\hline \hline Augmented Dickey-Fuller test statistic & -7.537464 & 0.0000 \\
\hline Test critical values: & 1\% level & -3.605593 & \\
& 10\% level & -2.936942 & \\
& & -2.606857 & \\
\hline \hline
\end{tabular}

*MacKinnon (1996) one-sided p-values.

Dependent Variable: D(SPOTPRICE,2)

Method: Least Squares

Date: 06/25/11 Time: 10:58

Sample (adjusted): 342 
Included observations: 40 after adjustments

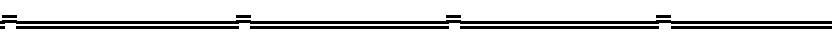

\section{Annexure-II}

Null Hypothesis: MCX Refined Soybean Oil Future Price has a unit root

Exogenous: Constant

Lag Length: 0 (Automatic based on SIC, MAXLAG=10)

\begin{tabular}{lrrr}
\hline \hline & t-Statistic & Prob. ${ }^{*}$ \\
\hline \hline Augmented Dickey-Fuller test statistic & -0.628738 & 0.8543 \\
\hline Test critical values: & 1\% level & -3.574446 & \\
& 5\% level & -2.923780 & \\
& $10 \%$ level & -2.599925 & \\
\hline \hline
\end{tabular}

*MacKinnon (1996) one-sided p-values.

Augmented Dickey-Fuller Test Equation

Dependent Variable: D(MCXFP)

Method: Least Squares

Date: 06/25/11 Time: $11: 55$

Sample (adjusted): 249

Included observations: 48 after adjustments

Null Hypothesis: D(MCX Refined Soybean Oil Future Price) has a unit root

Exogenous: Constant

Lag Length: 0 (Automatic based on SIC, MAXLAG=10)

\begin{tabular}{lccc}
\hline \hline & t-Statistic & Prob.* \\
\hline \hline \multicolumn{2}{l}{ Augmented Dickey-Fuller test statistic } & -7.093481 & 0.0000 \\
\hline Test critical values: $\quad$ 1\% level & -3.577723 & \\
& $5 \%$ level & -2.925169 & \\
& $10 \%$ level & -2.600658 & \\
\hline
\end{tabular}

*MacKinnon (1996) one-sided p-values.

Augmented Dickey-Fuller Test Equation

Dependent Variable: D(MCXFP,2)

Method: Least Squares

Date: 06/25/11 Time: 11:57

Sample (adjusted): 349

Included observations: 47 after adjustments

Null Hypothesis: Refined Soybean Oil Spot Price has a unit root

Exogenous: Constant

Lag Length: 0 (Automatic based on SIC, MAXLAG=10)

\begin{tabular}{lccc}
\hline \hline & t-Statistic & Prob.* \\
\hline \hline \multicolumn{2}{l}{ Augmented Dickey-Fuller test statistic } & -0.360911 & 0.9075 \\
\hline Test critical values: $\quad$ \% level & -3.571310 & \\
& 5\% level & -2.922449 & \\
& $10 \%$ level & -2.599224 & \\
\hline \hline
\end{tabular}

*MacKinnon (1996) one-sided p-values.

Augmented Dickey-Fuller Test Equation

Dependent Variable: D(SPOTPRICE)

Method: Least Squares

Date: 06/25/11 Time: 12:01 
Sample (adjusted): 250

Included observations: 49 after adjustments

Null Hypothesis: D(Refine Soybean Oil Spot Price) has a unit root Exogenous: Constant Lag Length: 0 (Automatic based on SIC, MAXLAG=10)

\begin{tabular}{lccc}
\hline \hline & t-Statistic & Prob.* \\
\hline \hline \multicolumn{2}{l}{ Augmented Dickey-Fuller test statistic } & -5.641948 & 0.0000 \\
\hline Test critical values: $\quad$ 1\% level & -3.574446 & \\
& 5\% level & -2.923780 & \\
& 10\% level & -2.599925 & \\
\hline \hline
\end{tabular}

*MacKinnon (1996) one-sided p-values.

Augmented Dickey-Fuller Test Equation Dependent Variable: D(SPOTPRICE,2)

Method: Least Squares

Date: 06/25/11 Time: 12:03

Sample (adjusted): 350

Included observations: 48 after adjustments

\section{Annexure-III}

Null Hypothesis: WHEATFP has a unit root

Exogenous: Constant

Lag Length: 0 (Automatic based on SIC, MAXLAG=5)

\begin{tabular}{llll}
\hline \hline & t-Statistic & Prob. ${ }^{*}$ \\
\hline \hline Augmented Dickey-Fuller test statistic & -0.903953 & 0.7692 \\
\hline Test critical values: & 1\% level & -3.737853 & \\
& 5\% level & -2.991878 & \\
& 10\% level & -2.635542 & \\
\hline \hline
\end{tabular}

*MacKinnon (1996) one-sided p-values.

Null Hypothesis: D(WHEATFP) has a unit root

Exogenous: Constant

Lag Length: 0 (Automatic based on SIC, MAXLAG=5)

\begin{tabular}{lccc}
\hline \hline & t-Statistic & Prob.* \\
\hline \hline Augmented Dickey-Fuller test statistic & -6.102023 & 0.0000 \\
\hline Test critical values: & 1\% level & -3.752946 & \\
& 5\% level & -2.998064 & \\
& $10 \%$ level & -2.638752 & \\
\hline \hline
\end{tabular}

*MacKinnon (1996) one-sided p-values.

Null Hypothesis: WHEATSP has a unit root

Exogenous: Constant

Lag Length: 1 (Automatic based on SIC, MAXLAG=5)

\begin{tabular}{lcc}
\hline \hline & t-Statistic & Prob.* \\
\hline \hline Augmented Dickey-Fuller test statistic & -1.367487 & 0.5799 \\
\hline Test critical values: $\quad$ 1\% level & -3.752946 &
\end{tabular}




$\begin{array}{ll}5 \% \text { level } & -2.998064 \\ 10 \% \text { level } & -2.638752\end{array}$

*MacKinnon (1996) one-sided p-values.

Null Hypothesis: D(WHEATSP) has a unit root

Exogenous: Constant

Lag Length: 0 (Automatic based on SIC, MAXLAG=5)

\begin{tabular}{lcc}
\hline \hline & t-Statistic \\
\hline \hline Augmented Dickey-Fuller test statistic & -2.938184 \\
\hline Test critical values: & 1\% level & -3.752946 \\
& $5 \%$ level & -2.998064 \\
& $10 \%$ level & -2.638752 \\
\hline \hline
\end{tabular}

*MacKinnon (1996) one-sided p-values.

\section{Annexure-IV}

Null Hypothesis: RUBBERFP has a unit root

Exogenous: Constant

Lag Length: 1 (Automatic based on SIC, MAXLAG=9)

\begin{tabular}{lccc}
\hline \hline & & t-Statistic & Prob.* \\
\hline \hline \multicolumn{2}{l}{ Augmented Dickey-Fuller test statistic } & -1.810909 & 0.3698 \\
\hline Test critical values: $\quad$ 1\% level & -3.615588 & \\
& 5\% level & -2.941145 & \\
& 10\% level & -2.609066 & \\
\hline \hline
\end{tabular}

*MacKinnon (1996) one-sided p-values.

Null Hypothesis: D(RUBBERFP) has a unit root

Exogenous: None

Lag Length: 0 (Automatic based on SIC, MAXLAG=9)

\begin{tabular}{llll}
\hline \hline & t-Statistic & Prob.* \\
\hline \hline Augmented Dickey-Fuller test statistic & -4.505506 & 0.0000 \\
\hline Test critical values: & 1\% level & -2.627238 & \\
& $5 \%$ level & -1.949856 & \\
& $10 \%$ level & -1.611469 & \\
\hline \hline
\end{tabular}

*MacKinnon (1996) one-sided p-values.

Null Hypothesis: RUBBERSP has a unit root

Exogenous: None

Lag Length: 0 (Automatic based on SIC, MAXLAG=9)

\begin{tabular}{lccc}
\hline \hline & t-Statistic & Prob.* \\
\hline \hline Augmented Dickey-Fuller test statistic & 1.439679 & 0.9603 \\
\hline Test critical values: $\quad$ 1\% level & -2.625606 & \\
& 5\% level & -1.949609 & \\
& $10 \%$ level & -1.611593 & \\
\hline \hline
\end{tabular}

*MacKinnon (1996) one-sided p-values.

Null Hypothesis: D(RUBBERSP) has a unit root

Exogenous: None 
Lag Length: 0 (Automatic based on SIC, MAXLAG=9)

\begin{tabular}{llll}
\hline \hline & t-Statistic & Prob.* \\
\hline \hline Augmented Dickey-Fuller test statistic & -4.512654 & 0.0000 \\
\hline Test critical values: & 1\% level & -2.627238 & \\
& 5\% level & -1.949856 & \\
& $10 \%$ level & -1.611469 & \\
\hline \hline
\end{tabular}

*MacKinnon (1996) one-sided p-values.

\section{Annexure-V}

Null Hypothesis: MCX Future Price has a unit root

Exogenous: Constant

Lag Length: 0 (Automatic based on SIC, MAXLAG=9)

\begin{tabular}{lrrr}
\hline \hline & t-Statistic & \multirow{2}{*}{ Prob. $^{*}$} \\
\hline \hline Augmented Dickey-Fuller test statistic & -0.456908 & 0.8903 \\
\hline Test critical values: & 1\% level & -3.577723 & \\
& 5\% level & -2.925169 & \\
& $10 \%$ level & -2.600658 & \\
\hline \hline
\end{tabular}

*MacKinnon (1996) one-sided p-values.

Augmented Dickey-Fuller Test Equation

Dependent Variable: D(MCXFP)

Method: Least Squares

Date: 06/25/11 Time: $12: 59$

Sample (adjusted): 248

Included observations: 47 after adjustments

Null Hypothesis: D(MCX Future Price) has a unit root

Exogenous: Constant

Lag Length: 0 (Automatic based on SIC, MAXLAG=9)

\begin{tabular}{lccc}
\hline \hline & t-Statistic & Prob.* \\
\hline \hline Augmented Dickey-Fuller test statistic & -8.433384 & 0.0000 \\
\hline Test critical values: & 5\% level & -3.581152 & \\
& $10 \%$ level & -2.926622 & \\
& -2.601424 & \\
\hline
\end{tabular}

*MacKinnon (1996) one-sided p-values.

Augmented Dickey-Fuller Test Equation

Dependent Variable: D(MCXFP,2)

Method: Least Squares

Date: 06/25/11 Time: 13:00

Sample (adjusted): 348

Included observations: 46 after adjustments

Null Hypothesis: COMEX Future Price has a unit root

Exogenous: Constant

Lag Length: 0 (Automatic based on SIC, MAXLAG=9)

\begin{tabular}{|c|c|c|}
\hline & t-Statistic & Prob.* \\
\hline Augmented Dickey-Fuller test statistic & -4.380917 & 0.0010 \\
\hline Test critical values: & -3.577723 & \\
\hline
\end{tabular}




$\begin{array}{ll}5 \% \text { level } & -2.925169 \\ 10 \% \text { level } & -2.600658\end{array}$

*MacKinnon (1996) one-sided p-values.

Augmented Dickey-Fuller Test Equation

Dependent Variable: D(COMEXFP)

Method: Least Squares

Date: 06/25/11 Time: 13:02

Sample (adjusted): 248

Included observations: 47 after adjustments

Null Hypothesis: D(COMEX Future Price) has a unit root

Exogenous: Constant

Lag Length: 1 (Automatic based on SIC, MAXLAG=9)

\begin{tabular}{lccc}
\hline \hline & t-Statistic & Prob. ${ }^{*}$ \\
\hline \hline Augmented Dickey-Fuller test statistic & -7.470420 & 0.0000 \\
\hline Test critical values: & 5\% level & -3.584743 & \\
& $10 \%$ level & -2.928142 & \\
\hline \hline
\end{tabular}

*MacKinnon (1996) one-sided p-values.

Augmented Dickey-Fuller Test Equation

Dependent Variable: D(COMEXFP,2)

Method: Least Squares

Date: 06/25/11 Time: 13:03

Sample (adjusted): 448

Included observations: 45 after adjustments 